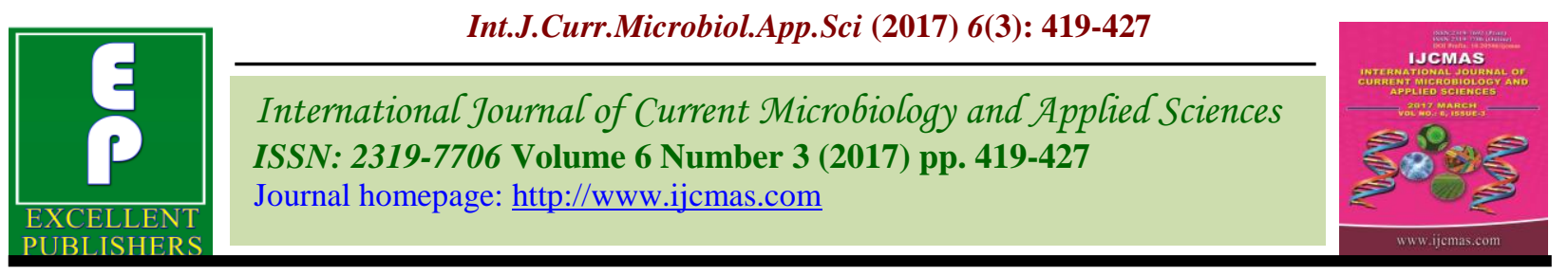

Original Research Article

https://doi.org/10.20546/ijcmas.2017.603.048

\title{
Rheological Behavior of Honey-Cereal Extrudates as a Function of Extrusion Processing Parameters
}

\author{
Hanuman Bobade*, Savita Sharma and Baljit Singh
}

Department of Food Science and Technology, Punjab Agricultural University, Ludhiana, Punjab, India

*Corresponding author

\begin{tabular}{|c|c|}
\hline & A B S T R A C T \\
\hline $\begin{array}{l}\text { Ke y w o r d s } \\
\text { Honey, Cereals, } \\
\text { Extrusion, } \\
\text { Rheology, Rapid } \\
\text { visco analyzer. } \\
\end{array}$ & \multirow{3}{*}{$\begin{array}{l}\text { Rheological characteristics of honey-whole grain cereal extrudates as influenced by } \\
\text { varying extrusion processing conditions were studied. Honey, blended at various level with } \\
\text { the cereal flours at } 14 \text { and } 17 \% \text { feed moisture, was subjected to extrusion processing at } \\
\text { different extrusion temperatures. The rheological properties of the resultant extrudates } \\
\text { were measured by rapid visco analyzer. It was observed that all the processing conditions } \\
\text { significantly affected the rheological properties of the extrudates. Increased extrusion } \\
\text { temperature resulted in decreased viscosity of the extrudates. Highest values of rheological } \\
\text { characteristics were recorded at lowest extrusion temperature. Honey addition positively } \\
\text { influenced the viscosity of extrudates. Addition of honey in the feed resulted in increased } \\
\text { rheological characteristics of resultant extrudates. Amongst the rheological characteristics, } \\
\text { peak viscosity and final viscosity was found mostly affected by the extrusion parameters. }\end{array}$} \\
\hline Article Info & \\
\hline $\begin{array}{l}\text { Accepted: } \\
\text { 10 February } 2017 \\
\text { Available Online: } \\
10 \text { March } 2017\end{array}$ & \\
\hline
\end{tabular}

\section{Introduction}

Extrusion cooking as an attractive process for continuous food production has been extensively developed in recent years. The high temperature-short time extrusion cooking is used in the food industry to produce direct expanded products such as snack foods, breakfast cereals and pet foods (Miller, 1990; Moore, 1994; Rokey, 1994). Extrusion of food material results in starch gelatinization, denaturation of protein, microbial reduction, enzyme activation or inactivation, color and other changes. The extents of these changes are dependent on the conditions of the extrusion. Those changes at the constituents' level modify the rheological behavior of flour batters (Hagenimana et al., 2006).
Refined cereal flours are chiefly utilized in preparation extruded snacks owing to high expansion capability of these cereal flours. However, such refined cereal flours being rich in mere carbohydrate and proteins lack nutritional quality. Hence, in order to provide consumers nutritionally superior extruded snacks, these days, whole grain cereal flours are being increasingly used. Contrary to the refined cereal flours, the whole grain cereal flours produces snacks with decreased expansion and unattractive physical appearance due to high fiber content.

This is mainly due to altered rheological behavior of whole cereal flour extrudates. In order to increase the nutritional quality of 
extruded snacks, the cereal flours are also being supplemented with other ingredients such as fruits and vegetables, legumes, milk solids and others. Moreover, there is growing interest of consumers in more differentiated food products in recent years (Stolzenbach et $a l ., 2013)$. In this context, usage of honey as a source of bioactive and nutritionally rich ingredient in formulation of extruded products will be prolific.

Rheological changes during extrusion of refined cereal flour with conventional ingredients are reasonably predictable and modestly established. Nevertheless, rheological behavior of whole grain cereal flour is relatively complex. Hence, understanding of rheological changes of whole grain cereal flour with such ingredient as honey is important. Keeping in view this perspective, the study comprising of effect of extrusion processing on rheological properties of honey-whole grain cereals extrudates was undertaken.

\section{Materials and Methods}

Wheat (var. HD 2967), paddy (var. PR 121), maize (var. PMH 1) was supplied by Directorate Seeds, Punjab Agricultural University, Ludhiana, Punjab, India. Brown rice was obtained by dehulling the paddy in laboratory dehuller (Satake, Japan). Wheat, brown rice and maize after cleaning were grinded in Torrento Flour Mill (Tech Electric Enterprise, Ahmedabad, India) to obtain the whole grain flours $(250 \mu)$. Honey (sunflower cultivar) was supplied by Department of Entomology, Punjab Agricultural University, Ludhiana, India.

\section{Experimental design}

Feed moisture and extrusion temperature were observed from literature as most critical factors affecting extrudate characteristics.
Honey level, as seen through experimental trials, was also significantly affecting the extrudate properties. The extrusion was carried out by varying the levels of three independent variables (feed moisture, extrusion temperature and honey level in the feed). The feed moisture was varied at two levels ( $14 \& 17 \%)$, extrusion temperature was varied at 5 levels $(100,120,140,180 \&$ $200^{\circ} \mathrm{C}$ ) while honey level was varied at 5 different levels $(1,5,10,15 \& 20 \%)$. Three types of cereals (wheat, rice, maize) singly and in combination (3:4:3 proportion, which was decided after preliminary trials) were mixed with the honey and extruded at varying feed moisture and extrusion temperature. The levels of independent variables were established based on observations of preliminary trials and literature survey.

\section{Extrusion}

Extrusion of honey-cereals was performed with the help of twin screw co-rotating intermeshing extruder (BC 21, Clextral, Firminy, France) having a screw length of $400 \mathrm{~mm}$ and diameter $25 \mathrm{~mm}$. The extruder was powered by an $8.5 \mathrm{~kW}$ motor with speeds variable from 0 to $682 \mathrm{rpm}$. Over entire experiment, the screw speed of the extruder was kept constant (500 rpm). Raw materials were metered into the extruder with a single screw volumetric feeder (D $\mathrm{S}$ and $\mathrm{M}$, Modena, Italy). The feed rate was kept at $10 \mathrm{~kg} / \mathrm{hr}$ rate for optimum filling in accordance with the screw speed. A variable speed die face cutter with four bladed knives was used to cut the extrudates. The die plate had one circular hole with $6 \mathrm{~mm}$ diameter.

\section{Rheological properties}

The extrudates were grinded to particle size less than $200 \mu \mathrm{m}$. Pasting properties (peak, trough, breakdown, final and setback viscosity) of samples extruded under different 
conditions were determined using a rapid visco-analyzer, RVA (Model StarchMaster2; Newport Scientific Inc., Warriewood, Australia). For each analysis, 3.0 $00.05 \mathrm{~g}$ samples (14\% wb) were mixed with $25 \mathrm{~mL}$ of distilled water. The profile for analysis was Standard Method 1 according to AACC (2000) Approved Method 76-21.

\section{Statistical analysis}

The analysis of variance was performed with the help of Statistical Package for the Social Sciences (SPSS, [PASW version 18.0] Inc., USA). Tukey's test $(p<0.05)$ was used to detect differences among treatment means.

\section{Results and Discussion}

\section{Rheological properties}

Rheological properties of honey-whole grain flours were significantly affected by extrusion processing parameters as well as the level of honey. Influence of extrusion processing parameters and level of honey on rheological properties of various cereal-honey extrudates is discussed in following sections.

\section{Honey-wheat extrudates}

The pasting properties of honey-wheat extrudates were measured by rapid visco analyzer and are presented in table 1 . Significant $\quad(p<0.05)$ differences were observed in the pasting properties of honeywheat extrudates. The highest peak viscosity was observed at lower extrusion temperature and lowest peak viscosity was observed at higher extrusion temperature for both feed moistures (14 and 17\%). The peak viscosity occurs at equilibrium point between swelling and polymer leaching which causes an increase in viscosity. It also indicates the water binding capacity of starch or mixture. The highest values of viscosity in the product may be associated with a high proportion of un-gelatinized starch, whereas the lowest values of viscosity might reflect greater degradation that is attributed to depolymerization and molecular entanglement resulting from the processing conditions (Hagenimana et al., 2006). At high temperature, the extruded mass becomes plastic and less viscous allowing the molecules to become more susceptible to compression during extrusion. Thus greater thermal and mechanical action was produced, resulting in degradation of the starch granules and subsequently, lower viscosity value was obtained. Similar observations were recorded by Hernandez-Nava et al., (2011).

The final viscosity which depends upon changes in the starch granule structure during extrusion processing varied from 110-302 cP for extrudates prepared at 14 per cent feed moisture and from $88-412 \mathrm{cP}$ for extrudates prepared at 17 per cent moisture and various levels of temperature and honey. Within 17 per cent feed moisture, the highest value of final viscosity was observed at $100^{\circ} \mathrm{C}$ barrel temperature and 10 per cent honey level while the lowest final viscosity was noted at $200^{\circ} \mathrm{C}$ barrel temperature and 10 per cent honey. Similar results were seen with respect to the final viscosity of extrudates prepared at 14 percent feed moisture. The final lower viscosity of extrusion processed extrudates was the result of starch liquification during processing at higher temperature. These observations are in corroboration with results of Zeng et al., 2011.

Breakdown viscosity of wheat-honey extrudates also decreased significantly with increase in extrusion temperature. The rate of breakdown depends on the temperature and degree of mixing or shear stress applied to the mixture and the nature of material itself. Increased addition of honey in feed had positive effect on the breakdown viscosity of 
extrudates. This could be due to the resistance offered by viscous honey against the degradation of starch during extrusion processing. The high rate of breakdown as a result of increased extrusion temperature might be attributed to excessive dextrinization of starch during extrusion. The setback viscosity of extrudates also lowered upon increase in extrusion temperature. Honey addition increased the setback viscosity of honey-wheat extrudates. During setback, cooling occurs and re-association between starch molecules, especially amylose resulted in formation of a gel structure and therefore viscosity increases during this phase. Setback viscosity is generally related to the retrogradation and reordering of starch granules.

\section{Honey-brown rice extrudates}

The pasting properties of honey-brown rice extrudates as determined using RVA are shown in table 2 . The pasting temperature of the samples was not detected, indicating that the extrudates were fully cooked during extrusion processing. The peak viscosity of the extrudates varied significantly $(p<0.05)$. Decrease in peak viscosity of extrudates with increase in extrusion temperature was observed. The peak viscosity of extrudates prepared at 17 per cent moisture, $100^{\circ} \mathrm{C}$ barrel temperature and 10 per cent honey levels was $385 \mathrm{cP}$ which decreased to $86 \mathrm{cP}$ when barrel temperature was increased to $200^{\circ} \mathrm{C}$. This suggests that the barrel temperature has profound negative effect on the peak viscosity of extrudates. Conversely, the honey level in feed facilitated the increase in viscosity. This could be due to full gelatinization and degradation of starch at elevated extrusion temperature. The highest values for peak viscosity of extrudates were associated with a high proportion of un-gelatinized starch, whereas the lowest values of peak viscosity indicate a proportion of gelatinized starch that is attributable to varying of degrees of depolymerization and molecular entanglement resulting from the processing conditions. Similar observation has been reported earlier (Barres et al., 1990; McPherson et al., 2000)

Maximum value of final viscosity was observed at lowest extrusion temperature while the minimum final viscosity of extrudates was observed at highest extrusion temperature. At constant feed moisture and honey level, increasing the barrel temperature resulted in decreased final viscosity of the extrudates while at constant feed moisture and barrel temperature, increased honey level in feed boosted up the final viscosity of extrudates. The results of this study thus indicate that the extrudates successively lose the ability to form a paste or gel after cooking and cooling when extrusion temperature is increased.

The breakdown viscosity of extrudates, which measures the ability of material to withstand the heating and shear stress, differed significantly $(p<0.05)$. Rapid decrease in breakdown and setback viscosity was noticed when the temperature of extrusion cooking was increased. The effect of honey level on the breakdown and setback viscosity was found exact opposite to the effect of extrusion temperature. However, the increase in these viscosities by increased honey level in feed was apprehensive. The results specify that reassociation or re-ordering of leached amyloseamylopectin molecules is hindered by increased extrusion temperature whereas honey aided in re-association of amylose and amylopectin molecules in the extrudates. The extensive gelatinization that the cereal flours undergo when subjected to severe extrusion intensity could promote the viscosity decrease during the heating-cooling cycle, as it was observed by Hagenimana et al., (2006) and Sharma et al., (2013). Moreover, the reduction observed in the final viscosity and 
setback (difference between the minimum viscosity during heating and the final viscosity after cooling) in flour subjected to harsh extrusion, indicated the extension of the effect on the amylose chains, which might lose the ability to retrograde during cooling owing to their fragmentation during extrusion.

Table.1 Rheological properties of honey-wheat extrudates

\begin{tabular}{cccccccc}
\hline & Treatments & \multicolumn{5}{c}{ Rheological properties } \\
\hline $\begin{array}{c}\text { Moisture } \\
(\%)\end{array}$ & $\begin{array}{c}\text { Temperature } \\
\left({ }^{\mathbf{0}} \mathbf{C}\right)\end{array}$ & $\begin{array}{c}\text { Honey } \\
(\%)\end{array}$ & $\begin{array}{c}\text { Peak } \\
\text { viscosity } \\
(\mathbf{c P})\end{array}$ & $\begin{array}{c}\text { Hold } \\
\text { viscosity } \\
(\mathbf{c P})\end{array}$ & $\begin{array}{c}\text { Final } \\
\text { viscosity } \\
(\mathbf{c P})\end{array}$ & $\begin{array}{c}\text { Breakdown } \\
\text { viscosity } \\
(\mathbf{c P})\end{array}$ & $\begin{array}{c}\text { Setback } \\
\text { viscosity } \\
(\mathbf{c P})\end{array}$ \\
\hline \multirow{4}{*}{14} & 120 & 5 & $336^{\mathrm{a}}$ & $71^{\mathrm{b}}$ & $289^{\mathrm{b}}$ & $265^{\mathrm{a}}$ & $218^{\mathrm{a}}$ \\
& 180 & 5 & $152^{\mathrm{b}}$ & $21^{\mathrm{c}}$ & $110^{\mathrm{d}}$ & $131^{\mathrm{c}}$ & $89^{\mathrm{c}}$ \\
& 120 & 15 & $354^{\mathrm{c}}$ & $86^{\mathrm{a}}$ & $302^{\mathrm{a}}$ & $268^{\mathrm{a}}$ & $216^{\mathrm{a}}$ \\
& 180 & 15 & $187^{\mathrm{d}}$ & $27^{\mathrm{c}}$ & $144^{\mathrm{c}}$ & $160^{\mathrm{b}}$ & $117^{\mathrm{b}}$ \\
\hline \multirow{4}{*}{17} & 100 & 10 & $412^{\mathrm{a}}$ & $95^{\mathrm{a}}$ & $361^{\mathrm{a}}$ & $317^{\mathrm{a}}$ & $266^{\mathrm{a}}$ \\
& 200 & 10 & $88^{\mathrm{e}}$ & $15^{\mathrm{d}}$ & $80^{\mathrm{e}}$ & $73^{\mathrm{e}}$ & $65^{\mathrm{e}}$ \\
& 150 & 1 & $239^{\mathrm{d}}$ & $38^{\mathrm{c}}$ & $195^{\mathrm{d}}$ & $201^{\mathrm{d}}$ & $157^{\mathrm{d}}$ \\
& 150 & 20 & $297^{\mathrm{b}}$ & $59^{\mathrm{b}}$ & $272^{\mathrm{b}}$ & $238^{\mathrm{b}}$ & $213^{\mathrm{b}}$ \\
& 150 & 10 & $268^{\mathrm{c}}$ & $51^{\mathrm{b}}$ & $242^{\mathrm{c}}$ & $217^{\mathrm{c}}$ & $191^{\mathrm{c}}$ \\
\hline
\end{tabular}

Means followed by different superscript letter in the column differ significantly $(\mathrm{p}<0.05)$ for a given feed moisture.

Table.2 Rheological properties of honey-brown rice extrudates

\begin{tabular}{cccccccc}
\hline & Treatments & \multicolumn{5}{c}{ Rheological properties } \\
\hline $\begin{array}{c}\text { Moisture } \\
(\%)\end{array}$ & $\begin{array}{c}\text { Temperature } \\
(\mathbf{0} \mathbf{C})\end{array}$ & $\begin{array}{c}\text { Honey } \\
(\%)\end{array}$ & $\begin{array}{c}\text { Peak } \\
\text { viscosity } \\
(\mathbf{c P})\end{array}$ & $\begin{array}{c}\text { Hold } \\
\text { viscosity } \\
(\mathbf{c P})\end{array}$ & $\begin{array}{c}\text { Final } \\
\text { viscosity } \\
(\mathbf{c P})\end{array}$ & $\begin{array}{c}\text { Breakdown } \\
\text { viscosity } \\
(\mathbf{c P})\end{array}$ & $\begin{array}{c}\text { Setback } \\
\text { viscosity } \\
(\mathbf{c P})\end{array}$ \\
\hline \multirow{4}{*}{14} & 120 & 5 & $298^{\mathrm{b}}$ & $62^{\mathrm{b}}$ & $268^{\mathrm{b}}$ & $236^{\mathrm{b}}$ & $206^{\mathrm{a}}$ \\
& 180 & 5 & $142^{\mathrm{d}}$ & $16^{\mathrm{c}}$ & $91^{\mathrm{d}}$ & $126^{\mathrm{d}}$ & $75^{\mathrm{c}}$ \\
& 120 & 15 & $331^{\mathrm{a}}$ & $74^{\mathrm{a}}$ & $288^{\mathrm{a}}$ & $257^{\mathrm{a}}$ & $214^{\mathrm{a}}$ \\
& 180 & 15 & $174^{\mathrm{c}}$ & $19^{\mathrm{c}}$ & $128^{\mathrm{c}}$ & $155^{\mathrm{c}}$ & $109^{\mathrm{b}}$ \\
\hline \multirow{3}{*}{17} & 100 & 10 & $385^{\mathrm{a}}$ & $86^{\mathrm{a}}$ & $308^{\mathrm{a}}$ & $299^{\mathrm{a}}$ & $222^{\mathrm{a}}$ \\
& 200 & 10 & $86^{\mathrm{e}}$ & $12^{\mathrm{d}}$ & $68^{\mathrm{e}}$ & $74^{\mathrm{e}}$ & $56^{\mathrm{d}}$ \\
& 150 & 1 & $219^{\mathrm{d}}$ & $31^{\mathrm{c}}$ & $192^{\mathrm{d}}$ & $188^{\mathrm{d}}$ & $161^{\mathrm{c}}$ \\
& 150 & 20 & $283^{\mathrm{b}}$ & $46^{\mathrm{b}}$ & $247^{\mathrm{b}}$ & $237^{\mathrm{b}}$ & $201^{\mathrm{b}}$ \\
& 150 & 10 & $248^{\mathrm{c}}$ & $39 \mathrm{~b}^{\mathrm{c}}$ & $232^{\mathrm{c}}$ & $209^{\mathrm{c}}$ & $193^{\mathrm{b}}$ \\
\hline
\end{tabular}

Column wise, means followed by superscript letter within moisture differs significantly $(P<0.05)$. 
Table.3 Rheological properties of honey-maize extrudates

\begin{tabular}{cccccccc}
\hline & Treatments & \multicolumn{5}{c}{ Rheological properties } \\
\hline $\begin{array}{c}\text { Moisture } \\
(\%)\end{array}$ & $\begin{array}{c}\text { Temperature } \\
(\mathbf{0} \mathbf{C})\end{array}$ & $\begin{array}{c}\text { Honey } \\
(\%)\end{array}$ & $\begin{array}{c}\text { Peak } \\
\text { viscosity } \\
(\mathbf{c P})\end{array}$ & $\begin{array}{c}\text { Hold } \\
\text { viscosity } \\
(\mathbf{c P})\end{array}$ & $\begin{array}{c}\text { Final } \\
\text { viscosity } \\
(\mathbf{c P})\end{array}$ & $\begin{array}{c}\text { Breakdown } \\
\text { viscosity } \\
(\mathbf{c P})\end{array}$ & $\begin{array}{c}\text { Setback } \\
\text { viscosity } \\
(\mathbf{c P})\end{array}$ \\
\hline \multirow{4}{*}{14} & 120 & 5 & $368^{\mathrm{b}}$ & $81^{\mathrm{a}}$ & $322^{\mathrm{b}}$ & $287^{\mathrm{a}}$ & $241^{\mathrm{b}}$ \\
& 180 & 5 & $162^{\mathrm{d}}$ & $25^{\mathrm{b}}$ & $124^{\mathrm{d}}$ & $137^{\mathrm{c}}$ & $99^{\mathrm{d}}$ \\
& 120 & 15 & $385^{\mathrm{a}}$ & $86^{\mathrm{a}}$ & $340^{\mathrm{a}}$ & $299^{\mathrm{a}}$ & $254^{\mathrm{a}}$ \\
& 180 & 15 & $197^{\mathrm{c}}$ & $28^{\mathrm{b}}$ & $153^{\mathrm{c}}$ & $169^{\mathrm{b}}$ & $125^{\mathrm{c}}$ \\
\hline \multirow{4}{*}{17} & 100 & 10 & $431^{\mathrm{a}}$ & $107^{\mathrm{a}}$ & $387^{\mathrm{a}}$ & $324^{\mathrm{a}}$ & $280^{\mathrm{a}}$ \\
& 200 & 10 & $94^{\mathrm{e}}$ & $17^{\mathrm{d}}$ & $85^{\mathrm{e}}$ & $77^{\mathrm{d}}$ & $68^{\mathrm{e}}$ \\
& 150 & 1 & $251^{\mathrm{d}}$ & $43^{\mathrm{c}}$ & $216^{\mathrm{d}}$ & $208^{\mathrm{c}}$ & $173^{\mathrm{d}}$ \\
& 150 & 20 & $309^{\mathrm{b}}$ & $67^{\mathrm{b}}$ & $284^{\mathrm{b}}$ & $242^{\mathrm{b}}$ & $217^{\mathrm{b}}$ \\
& 150 & 10 & $279^{\mathrm{c}}$ & $58^{\mathrm{b}}$ & $251^{\mathrm{c}}$ & $221^{\mathrm{c}}$ & $193^{\mathrm{c}}$ \\
\hline
\end{tabular}

Means followed by different superscript letter in the column differ significantly $(\mathrm{p}<0.05)$ for a given feed moisture

Table.4 Rheological properties of honey-cereals in combination extrudates

\begin{tabular}{cccccccc}
\hline & Treatments & \multicolumn{5}{c}{ Rheological properties } \\
\hline $\begin{array}{c}\text { Moisture } \\
(\%)\end{array}$ & $\begin{array}{c}\text { Temperature } \\
(\mathbf{C} \mathbf{C})\end{array}$ & $\begin{array}{c}\text { Honey } \\
(\%)\end{array}$ & $\begin{array}{c}\text { Peak } \\
\text { viscosity } \\
(\mathbf{c P})\end{array}$ & $\begin{array}{c}\text { Hold } \\
\text { viscosity } \\
(\mathbf{c P})\end{array}$ & $\begin{array}{c}\text { Final } \\
\text { viscosity } \\
(\mathbf{c P})\end{array}$ & $\begin{array}{c}\text { Breakdown } \\
\text { viscosity } \\
(\mathbf{c P})\end{array}$ & $\begin{array}{c}\text { Setback } \\
\text { viscosity } \\
(\mathbf{c P})\end{array}$ \\
\hline \multirow{4}{*}{14} & 120 & 5 & $342^{\mathrm{b}}$ & $76^{\mathrm{a}}$ & $311^{\mathrm{a}}$ & $266^{\mathrm{b}}$ & $235^{\mathrm{a}}$ \\
& 180 & 5 & $150^{\mathrm{d}}$ & $20^{\mathrm{b}}$ & $106^{\mathrm{c}}$ & $130^{\mathrm{d}}$ & $86^{\mathrm{c}}$ \\
& 120 & 15 & $364^{\mathrm{a}}$ & $83^{\mathrm{a}}$ & $318^{\mathrm{a}}$ & $281^{\mathrm{a}}$ & $235^{\mathrm{a}}$ \\
& 180 & 15 & $172^{\mathrm{c}}$ & $23^{\mathrm{b}}$ & $140^{\mathrm{b}}$ & $149^{\mathrm{c}}$ & $117^{\mathrm{b}}$ \\
\hline \multirow{3}{*}{17} & 100 & 10 & $418^{\mathrm{a}}$ & $102^{\mathrm{a}}$ & $373^{\mathrm{a}}$ & $316^{\mathrm{a}}$ & $271^{\mathrm{a}}$ \\
& 200 & 10 & $90^{\mathrm{e}}$ & $14^{\mathrm{d}}$ & $81^{\mathrm{e}}$ & $76^{\mathrm{d}}$ & $67^{\mathrm{e}}$ \\
& 150 & 1 & $242^{\mathrm{d}}$ & $41^{\mathrm{c}}$ & $201^{\mathrm{d}}$ & $201^{\mathrm{c}}$ & $160^{\mathrm{d}}$ \\
& 150 & 20 & $286^{\mathrm{b}}$ & $57^{\mathrm{b}}$ & $268^{\mathrm{b}}$ & $229^{\mathrm{b}}$ & $211^{\mathrm{b}}$ \\
& 150 & 10 & $264^{\mathrm{c}}$ & $53^{\mathrm{b}}$ & $241^{\mathrm{c}}$ & $211^{\mathrm{c}}$ & $188^{\mathrm{c}}$ \\
\hline
\end{tabular}

Column wise, means followed by superscript letter within moisture differs significantly $(P<0.05)$.

\section{Honey-maize extrudates}

The pasting characteristics such as peak viscosity, final viscosity, breakdown viscosity and setback viscosity of the extrudates prepared from maize and honey at varying level and processing conditions differed significantly $(\mathrm{p}<0.05)$. It was observed that at 
both the feed moisture and at all the honey levels, the maximum values of pasting characteristics were observed at lower extrusion temperature whereas the minimum values were found at higher extrusion temperature. The extrusion temperature at 17 per cent feed moisture and 10 per cent honey level also adversely affected the pasting characteristics. The effect of extrusion temperature on pasting characteristics was such drastic that the reduction in viscosity by increasing temperature from 120 to $180^{\circ} \mathrm{C}$ was more than half. Xie et al., (2009) reported that the apparent viscosity of corn starch generally decreased with increasing temperature from 110 to $140^{\circ} \mathrm{C}$. The abrupt decrease in the viscosity of extrudates by increased extrusion temperature could be attributable to excessive polymer leaching and disorganization of ordered granular structure of starch, amylose and amylopectin molecules.

It is evident from table 3 that quantity of honey added in the feed has marked influence on the pasting characteristics of extrudates. At all the levels, honey produced statistically $(\mathrm{p}<0.05)$ significant difference in peak viscosity, final viscosity, breakdown viscosity and setback viscosity. Similarly, at constant feed moisture of 14 per cent and extrusion temperature of $120^{\circ} \mathrm{C}$, the increase in honey level from 5 to 15 per cent resulted in increase in peak viscosity from 368 to $385 \mathrm{cP}$, final viscosity from 322 to $340 \mathrm{cP}$, breakdown viscosity from 287 to $299 \mathrm{cP}$ and setback viscosity from 241 to $254 \mathrm{cP}$. Similar increase in all pasting characteristics was examined when honey level in feed was increased at other feed moisture (14 and 17\%) and extrusion temperatures $\left(180\right.$ and $\left.150^{\circ} \mathrm{C}\right)$. The peak viscosity, which is indication of viscous load likely to be encountered during mixing, may have increased owing to natural viscous nature of honey. Honey might contribute in the formation of viscous paste and thereby increase in the final viscosity of mixture. As honey, due to its sticky character could resist the shear stress, may have enhanced the breakdown viscosity. The increase in setback viscosity on increased addition of honey in feed designate that it could hinder the reassociation and re-ordering of starch molecules in the mixture. The results of the present investigation with respect to pasting characteristics of extrudates are in agreement with the study of Martinez et al., (2014).

\section{Honey-cereals in combination extrudates}

The data pertaining to the pasting properties of combined cereals (wheat, rice and maize) and honey extrudates is reflected in table 4. Rapid Visco Analyzer did indicate the pasting temperature for none of the sample. This suggests that most of the starch present in the feed already underwent the gelatinization and cooking. It could be observed from the table 4 that peak viscosity, final viscosity, breakdown viscosity and setback viscosity reduced with increase in extrusion temperature. However, level of honey in feed was found to have positive effect on these pasting characteristics. The peak viscosity was found in the range of 90-418 cP, highest peak viscosity being observed at lowest temperature and vice versa. At intermediate extrusion temperature $\left(150^{\circ} \mathrm{C}\right)$ the peak viscosity observed was $264 \mathrm{cP}$. Increased honey level also found to affect the peak viscosity of extrudates, however, the effect was constructive. Increasing the honey level from 1 to 20 per cent increased the peak viscosity of extrudates from 242 to $286 \mathrm{cP}$.

Table 4 indicates that the final viscosity of extrudates decreased with increase in the extrusion temperature and increased with increase in honey level in the feed. At 17 per cent feed moisture and 10 per cent honey level in the feed, the final viscosity of extrudates decreased from 373 to $81 \mathrm{cP}$ when 
temperature of extrusion was increased from 100 to $200^{\circ} \mathrm{C}$. This could be due to the intensive molecular breakdown at the elevated extrusion temperature since the viscosity of a paste depends on the degree of gelatinization and molecular breakdown (El-Dash et al., 1983). Contrary to the effect of extrusion temperature an increase in final viscosity from 201 to $268 \mathrm{cP}$ was observed when the honey level in feed was varied from 1 to 20 per cent. All the treatments differed significantly $(\mathrm{p}<0.05)$ from each other at various processing conditions. This indicates that the effect of extrusion temperature and honey level in feed was not equal in magnitude.

Extrusion temperature and honey level in feed affected the breakdown viscosity and setback viscosity of extrudates quite similar to the peak and final viscosities. At 14 per cent feed moisture and 5 and 15 per cent honey level, increasing the extrusion temperature from 120 to $180^{\circ} \mathrm{C}$ almost halved the breakdown viscosity of extrudates. However such effect was not noticed when the honey level was increased from 5 to 15 per cent at both, 120 as well as $180^{\circ} \mathrm{C}$ extrusion temperature. This again verifies that the extrusion temperature was the dominant factor in governing the pasting properties of extrudates, over honey level. The highest setback viscosity was obtained at lower extrusion temperature while the lowest setback viscosity was observed at higher extrusion temperature. Pomeranz (1991) indicated that the setback viscosity of cooked starch pastes on cooling was mainly a result of re-association of leached amylose.

Honey was found to influence the setback viscosity of extrudates positively. Increasing the honey content in feed from 1 to $20 \%$ resulted in increase of setback viscosity from 160 to $211 \mathrm{cP}$. The results of the present study are in corroboration with the findings of Pitts et al., (2014) who reported significant increase in the viscosity of wheat-corn blend extrudates upon addition of sugar.

In conclusion, this study revealed that the rheological parameters of extrudates are significantly getting affected as a function of extrusion processing. Non-detection of pasting temperature indicated that the samples were undergone sufficient cooking on extrusion. Reduction in the rheological characteristics was attributed due to depolymerization of feed material as a function of increased extrusion temperature. Incremental addition of honey in the cereal flours lead to slight increase in the viscosity of extrudates. Hence honey addition in whole cereal flour is likely to enhance the textural characteristics of honey. The results of this study will help in modeling and optimizing the extrusion conditions for processing of whole grain cereal flour and liquid ingredient like honey in preparation of extruded snacks.

\section{References}

AACC. 2000. Approved Methods of American Association of Cereal Chemists. $10^{\text {th }}$ ed. The Association St. Paul, MN, USA.

Barres, C., Verges, B., Tayeb, J. and Della Valle, G. 1990. Transformation of wheat flour by extrusion cooking. Influence of screw configuration and operating conditions," Cereal Chem., 67: 427-433.

El-Dash, A., Gonzales, A.R. and Ciol, M. 1983. Response surface methodology in the control of thermoplastic extrusion of starch. J. Food Engg., 39: 129-152.

Hagenimana, A., Ding, X. and Fang, T. 2006. Evaluation of rice flour modified by extrusion cooking. J. Cereal Sci., 43: $38-46$.

Hernandez-Nava, R.G., Bello-Perez, L.A., Martın-Martınez, E.S., Hernandez- 
Sanchez, H. and Mora-Escobedo R. 2011. Effect of extrusion cooking on the functional properties and starch components of lentil/banana blends: response surface analysis. Revista Mexicana de Ingeniería Química, 10: 409-419.

Martinez, M., Rosell, C. M. and Gomez, M. 2014. Modification of wheat flour functionality and digestibility through different extrusion conditions. J. Food Engg., 143: 74-79.

McPherson, A.E., Bailey, T.B. and Jane, J. 2000. Extrusion of cross-linked hydroxypropylated corn starches. I. Pasting properties. Cereal Chem., 77: 320-325.

Miller, R.C. 1990. "Unit Operations and Equipment, IV. Extrusion and Extruders," in Breakfast Cereals and How They are Made, Fast, R. B., and Andgaldwell, E. F. Ed., pp. 1-31, American Association of Cereal Chemists, St. Paul, MN, USA.

Moore, G. 1994. "Snack food extrusion," in The Technology of Extrusion Cooking, Frame, N. Ed., pp. 111-143, American Association of Cereal Chemists, St. Paul, MN, USA.

Pitts, K.F., Favaro, J., Austin, P. and Day, L. 2014. Co-effect of salt and sugar on extrusion processing, rheology, structure and fracture mechanical properties of wheat corn blend. J. Food Engg., 127: 58-66.

Pomeranz, Y. 1991. Carbohydrates: Starch," in Functional properties of food components, Y. Pomeranz, Ed., pp. 2478, Academic Press, Inc, New York.

Rokey, G.J. 1994. "Petfood and fishfood extrusion," in The Technology of Extrusion Cooking, N. D. Frame, Ed., pp. 144-189, American Association of Cereal Chemists, St. Paul, MN, USA.

Sharma, P., Singh, V. and Subramanian, R. 2013. Pasting, swelling, and solubility characteristics of rice batter prepared from different wet grinding systems. Starch-Starke, 65: 374-381.

Stolzenbach, S., Bredie, W.L.P., Byrne, D.V. 2013. Consumer concepts in new product development of local foods: Traditional verses novel honeys. Food Res. Int., 52: 144-152.

Xie, F., Yu, L., Su, B., Liu, P., Wang, J., Liu, H. and Chen, L. 2009. Rheological properties of starches with different amylose/amylopectin ratios. Cereal Sci., 49: 371-377.

Zeng, J., Gao, H., Li, G. and Liang, X. 2011. Extruded corn flour changes the functionality of blends. Czeck J. Food Sci., 29: 520-527.

\section{How to cite this article:}

Hanuman Bobade, Savita Sharma and Baljit Singh. 2017. Rheological Behavior of HoneyCereal Extrudates as a Function of Extrusion Processing Parameters. Int.J.Curr.Microbiol.App.Sci. 6(3): 419-427. doi: https://doi.org/10.20546/ijcmas.2017.603.048 